\title{
Depiction of the Hegemonic Internalization of Socio-Cultural Biases: A Study of Sharankumar Limbale's The Outcaste
}

\author{
Suresh Kumar \\ Assistant Professor \\ Department of English \\ Govt. College Indora \\ Kangra, Himachal Pradesh, India \\ vijaysuresh8890@gmail.com
}

\begin{abstract}
Sharankumar Limbale (1956 b.) is a Marathi author who is primarily known for his autobiography Akkarmashi (1984) originally published in Marathi. Having been translated into several Indian languages, the English translation of the autobiography by Santosh Bhoomkar got published by Oxford University Press in 2003. This paper aims at the portrayal of the abject poverty, utter helplessness, and biases prevalent in the socio-cultural milieus while offering contemplation to the practices of untouchability or discrimination based on caste, like how the minds of the people in a particular culture or society are trained to internalize the particular behavioural patterns of the dominating class of society. The paper also analyzes the ironic attitude of the men of upper-caste like how do they wish to cherish the physical charm of the beautiful women of the outcastes secretly, whereas socially they seek complete dissociation from them. Everything leads to the ostracization of the outcastes overtly and the outcastes stop reacting to the discriminatory patterns of behaviour, thus, their indifference to these becomes their habit turning them senseless.
\end{abstract}


Keywords: Autobiography, Abject Poverty, Biases, Socio-Cultural Milieus, Untouchability, Behavioural Patterns, Ironic Attitude, Ostracization, Habit.

In his autobiography The Outcaste, Sharan Kumar Limbale presents the sum of varied experiences since his childhood. The portrayal of his family, village, school life, college experiences, and as an employee all mirror the society where he lived in. As Limbale's family lived in the village Maharwada,where the lower-caste people were pushed to peripheries and the villagers being the low caste were supposed to do odd jobs like removing the dead animals of the upper caste people, skinning the dead animals, sweeping the village streets, and working as labourers even unpaid ones. Being low-caste, Mahars were considered untouchables in society. He counts the difficult days of his grandmother Santamai, hardwork of his grandfather as a porter, the scarcities of the family, his mother's adultery, his mother's keepers, superstitions and dual attitudes of the upper caste people. Abject poverty, helplessness, discrimination based on caste and hypocrisy are the focal issues, the writer hints at in the novel.

While pondering over social and cultural subjects known as "prison notebooks", the term 'hegemony' becomes the most echoed concept of the Italian communist Antonio Gramsci who believes that a social class achieves a predominant influence and power, not by direct and overt means but succeeding in making its ideological views so pervasive that the subordinate classes unwittingly accept and participate in their oppression (Abrams 208).Whereas Ernesto Laclau and Chantal Mouffe in Hegemony and Socialist Strategy (1985) argue for the understanding of society grounded not in economic determinism but in the nature of language (Abrams 209).

In his essay "Mirror for Man" Clyde Kluckhohn defines culture as the total way of life of a people; the social legacy the individual acquires from his group; a way of thinking, 
feeling and believing; an abstraction from behaviour; a theory on the part of the anthropologist about how a group of people behave; a storehouse of pooled learning; a set of standardized orientations recurrent problems; learned behaviour; a mechanism for the normative regulation of behaviour; a set of techniques for adjusting with the external environment and to other men; a precipitate of history (Geertz 4-5). On the other hand, the meaning of culture for Clifford Geertz is a semiotic one. Agreeing with Max weber that man is an animal suspended in webs of significance he has spun. She considers culture those webs, and an analysis of it is to be interpretive one in search of meaning (Geertz 5).

The novelist reveals that how the mindsets of the low caste people consider the favourable norms of the dominating class justified in the society and whatever condition they are in, find equally convinced. Although some characters complain against the tyranny of fate, that is too occasional, ultimately resulting in a habit of not protesting against the injustice.The people of low caste start considering their extreme poverty, starvation like conditions, discrimination based on caste against them, superstitions, and attitudes of the high caste people appropriate. The classification of human beings in society began with the introduction of the Verna system that finds mention in Rigveda during the Vedik period. Such classification was purely based on skill or ability. Every individual had the liberty to change his Verna according to his skill or karma. In other words, Verna was not based on one's birth. With time, Manusmiriti also threw light on the Verna system and manipulated it. Now, birth began to be considered the basis of one's Verna. It started becoming rigid with time(Thapar 122-124). Even after the Independence of the country, the constitution makes special provisions for the emancipation of the downtrodden, but the process of ostracizing the lower caste people continues in various cultures and The Outcaste is an example of this. How hierarchical hegemonic socio-cultural structures silent the oppressed classes by suppressing their reactive tendencies, will analyze further. 
While showing the hierarchies in the matter of possessing natural resources Limbale says that the resources of superior quality and having prime locations were owned by dominating upper caste people whereas the inferior ones were left for the use of the low caste people. After school, he used to go to the river to swim. The high-caste villagers used to fill their water pots and their women used to wash their clothes upstream. Downstream the kunbies and shepherds used to collect water in their vessels and carried them off. They also used to wash their clothes and wash their buffaloes besides bathing themselves. The water at the lowest end was meant for Mahars. Limbale says, "I used to stand in the river, collect water in my cupped palms and drink it. One day some mother had washed her baby clothes that sent a lump of shit towards me. But is there anything purer than water? The water flowing down from up the river had already entered my stomach. I felt sick" (7). In other words, people had no choice but to comply with the world order.

Although the Constitution of India abolishes untouchability under Article 17 of Fundamental Rights, still the minds of the people are governed by the prevalent socio-cultural practices. Limbale sharing his school experiences says that Brahmin and Wani boys used to play kabaddi in the school which used to attract him and his friends but low caste, they were not allowed to join them, so they used to play separate games. The walls and the flour were smeared with a cow-dung paste every Saturday. He says, “At home, I wouldn't do even the smallest chore, but in the school, on Saturdays, I was made to do this duty that was allotted to me. A man from my community had to carry out such duties in the village for the high-caste people" (4). Whenever the school was held in the Marwari's mansion the Mahar students were made to sit on the floor whereas the upper-caste students were made to sit on the raised platform (5). The educational institutions are supposed to set examples in society but they prove paradoxical in this respect. The barbers' refusal to give a haircut to Limbale as a child (22), Shobhi's expression that a Mahar's touch can impure the drinking water (70), the 
cobbler's refusal to repair Limbale's footwear because of his identity as Mahar (75), provision of separate cups at Shivram's tea shop (76), prohibition of Mahars from fetching drinking water from Patil's well that has been dug up by the Mahar labourers itself (81) all present the acceptance of discriminatory practices in the society without questioning. Once Limbale dares to question the casteist practice and along with his friend Prashya lodges a complaint against Shivram in the police station for keeping separate cups for the Mahars in his tea shop. When the constable informs Shivram about the complaint, he gets enraged and shouts: "Everyone from the Maharwada has been drinking tea from that cup and saucer for the last twenty years. What have these boys taken into their heads? If I allow them to enter my hotel, no other customers will come to me"(78). Expressing his helplessness, he shouts at them that if they visit his home he will serve them food on his plates. Thereafter Prashya and Limbale decide not to share the matter with anyone else, but before they reach home everyone was aware of the event as they found everyone in the Maharwada against them for complaining against Shivram. Even the elders in the family advise them not to repeat the same in future. Based on evidence, one finds that either the people irrespective of castes have internalized the behavioural patterns of the society or if someone questions the established standards is made to understand and is silenced accordingly.

Thereafter, the novelist acquaints the readers with the location of the low-caste settlements on the peripheries of the villages, separate low-caste villages, their traditional roles of scavenging and removing the dead animals from the villages, sweeping village streets and abject poverty that reflects the socio-cultural conditioning of society. It is the abject poverty of the downtrodden that compel them to do odd jobs for the survival of their families. Hanoor or Maharwada is the village where Limbale spent his childhood where his mother Masabai lived which is characterized by the heaps of garbage, tin sheds, dogs, and pigs as the companions of children. Children spent their time playing on Jaganath Patil's garbage. After 
Limbale took admission to the college in Sholapur, his grandmother Santamai shifted along with his grandfather who worked as a porter at the village bus stand who used to live near it in the hut. The autobiography is overloaded with poignant instanced of abject poverty that forced the helpless to do anything for their survival. While sharing his childhood experiences Limbale says that he feels ashamed of his coarse bhakaris as the upper-caste students shared their refined bhakaris with the teachers along with a variety of delicious dishes. After lunch when the teacher tells the upper-caste students to collect the leftover and give it to the lowcaste ones. Everyone eats the leftover delightedly. When Limbale narrates this to his mother, she says, "Why didn't you get at least a small portion of it for me? Leftover food is nectar" (3). During the harvest season, Limbale used to accompany his grandmother to the fields to collect cow dung:

During the harvest when cattle grazed in the fields, they passed undigested grains of jowar in their dung. The grains were yellow and swollen. Santamai picked up such lumps of dung and on the way home washed the dung in the river water, collecting only clean grains. She then dried them in the sun. As they dried they shrank. We went home when the grains were dry. When Santamai came home, she ground the jowar grains into flour. (10)

Limbale's grandmother Santamai used to make bhakaris in the evening for him and his grandfather from the jowar collected from alms whereas, for her, she used to use the jowar collected from the dung. Once Limbale turns adamant to have a piece of bhakari, and while eating it he felt like eating dung. Finding unable to eat, he returns it to his grandmother. Limbale's claim that during his school days he never used the soap, scrubbed his body with stone while bathing in the river (16), most of the time, his sister's sleeping without eating anything (21), Limbale's act of helping others who used to wash their clothes with soap, just to use the foam for his clothes in return (26), Ithal Kamble's extreme deprivation (35), 
Gangoobai's use of baby Limbale for begging (37), worry of starvation at the unwellness of Limbale's grandfather (41), Santamai's helplessness to pay even for a cup of tea for the guest (44), having a bath in the open by females (72), and Limbale's wearing of used clothes for his college (83) all exhibit the mire of poverty of the downtrodden. Besides these, a night leaves indelible imprints in Limbale's heart when six of his college friends come with him to have a pilgrimage in his village. After reaching the bus stand, he serves them tea, in the meantime, they wish to go to his home for having a rest but it proved to be the most difficult question to answer. He writes,"We slept on a rug and pulled another one over ourselves. Santamai and Dada had nothing to sleep on nor anything to cover themselves with, so they sat on the bench throughout the night" (97). After the departure of friends when the grandmother does not light the clay stove, he finds that there was no flour. Limbale feels himself a misfit in matters of befriending people due to his critical economic condition and homelessness, but his grandparents are used to it.

The novelist further presents a kaleidoscopic portrayal of the characters who feel compelled to take up varied ways due to abject poverty and helplessness for their survival in society. At times some might feel like rebels but they too get pacified and offer themselves in the hand of circumstances considering their fate. Limbale's grandfather works hard irrespective of weak health and old age as a porter whereas Santamai sweeps the village streets and begs alms. Masamai haves affairs with Hanmanta Patil, and Kaka after her divorce from Ithal Kamble. She had two children from Kamble, Limbale from Hanmanta Patil and seven children from Kaka. She claims property in the names of her children from Kaka (56). Sharing his Liquor business experience, he writes, "Santamai and Masamai had separate furnaces. Even their customers were different. Santamai and Masamai, mother and daughter, carried on their business as efficiently as men. Our family lived in the liquor business. If a cup was sold, it paid our morning tea. Sometimes there was no customer, so we went hungry. 
We waited for the customer if we were waiting for God" (28). Fetching drinking water from the dirty river even after digging up wells for the upper caste people, considering the leftover food as nectar by Mahars, overeating on the occasion of some village feasts and even sleeping after just drinking water without having any food are the practices with the low-caste people got adapted overtime.

Dual Standards of the upper-caste people remain an integral part of the novel. The upper-caste men from the prestigious families usually had their keeps who belonged to the low-castes. Having such adulterous affairs was an open secret in this scenario. Limbale's mother had the similar affair with Patils like Hanmanta and Kaka respectively. Whenever Masamai visits Kaka's mansion, she is served tea by Kaka's wife. Masamai is also known by Kaka's parents but they never wish to get spread the affair in society. The upper-caste men do not eat food made by Mahars but they do cherish the low-caste women physically. Such dual standards are considered normal in the novel.

The above analysis shows that socio-cultural circumstances play a crucial role in driving the lives of people in society across the globe. The dominating air in any sociocultural milieus cannot be changed overnight and The Outcaste exemplifies the same. The behavioural patterns, rituals, customs, faith, superstitions, beliefs, values or ethics of centuries get internalized in the personalities of the inhabitants, hence, become an integral part of their habits. Even the constitutional provisions prove a failure to bring any change. Numerous instances of discrimination based on caste, starvation like condition, helplessness compelling the poor to do anything for the sake of survival, hierarchical divisions of natural resources, description of Mahar settlements on fringes, and dual attitudes of the people all reflect the hegemonic internalization of socio-culturally biased patterns in the novel. 


\section{Works Cited}

Abrams, M.H., and Geoffrey Galt Harpham. A Glossary of Literary Terms. Cengage Learning India Private Limited, 2018.

Bakshi, P.M. The Constitution of India. Universal Law Publishing Co. Pvt. Ltd., 1997.

Geertz, Clifford. The Interpretation of Cultures. Basic Books, Inc., 1973.

Limbale, Sharan Kumar. The Outcaste. Trans. Santosh Bhoomkar. Oxford Umiversity Press, 2008.

Thapar, Romila. The Penguin History of Early India. Penguin Books Ltd., 2003. 